\title{
The relation between chronic polyneuropathy and osteosclerotic myeloma
}

\author{
J. B. MORLEY AND A. C. SCHWIEGER \\ From Prince Henry's Hospital, Melbourne, Australia
}

Recently attention has been directed to the various non-metastatic neurological manifestations of malignant diseases, and myeloma, noted for its presentation by signs of compression and infiltration, is less widely known in association with chronic symmetrical polyradiculoneuropathy. This paper discusses certain clinical aspects of this neuropathy.

We have found 16 accounts of the association with multiple myeloma (Table I), and seven with 'single' myeloma (Table II). These numbers do not include certain other reports (Kurnick and Yolahem, 1948, cases 1 and 3; Madonick and Solomon, 1953; Victor, Banker, and Adams, 1958, case 5; Williams, Diamond, Craver, and Parsons, 1959, case J. G.; Barron, Rowland, and Zimmerman, 1960; and Bibliography ${ }^{1-12}$ ), some of which do not describe the cases; in some the clinical picture was complicated by myelomatous compression or infiltration, or amyloid deposition, and in some the neuropathy was not a chronic symmetrical polyradiculoneuropathy. In two recent descriptions the writers comment on the unusual osteosclerotic myeloma in their cases (Small, Moxon, and Woolf, 1961; Aguayo, Thompson, and Humphrey, 1964), and ask whether this is more than a chance association. By reporting four more cases and reviewing the literature, we conclude that this concurrence is significant. In addition, our observations indicate that if the myeloma can be controlled, this otherwise fatal neuropathy is reversible.

\section{CASE REPORTS}

CASE 1 (PRINCE HENRY'S HOSPITAL NO. N4487) W.E.W., a 51-year-old male compositor, presented in January 1965 with aching, numbness, and weakness in both feet and numbness in the hands for one month. Examination revealed marked depression of all deep tendon reflexes,

TABLE I

\begin{tabular}{|c|c|c|c|c|c|c|c|c|}
\hline \multirow[b]{2}{*}{ Series } & \multicolumn{2}{|c|}{ MULTIPLE } & \multicolumn{2}{|c|}{ MYELOMA WITH } & \multirow[b]{2}{*}{$\begin{array}{l}\text { Duration of } \\
\text { Neuropathy }\end{array}$} & \multirow[b]{2}{*}{ Treatment } & \multirow[b]{2}{*}{ Fate } & \multirow[b]{2}{*}{$\begin{array}{l}\text { Neuro- } \\
\text { pathology }\end{array}$} \\
\hline & Age & Sex & $\begin{array}{l}\text { Reticuloendothelial } \\
\text { Abnormality }\end{array}$ & $\begin{array}{l}\text { C.S.F. } \\
\text { Protein }\end{array}$ & & & & \\
\hline \multicolumn{9}{|l|}{ Osteosclerotic radiological features } \\
\hline Crow (1956) case 1 & 54 & $\mathbf{M}$ & Lymphadenopathy & 400 & 36 months & $\begin{array}{l}\text { Radioactive phosphorus, } \\
\text { stilbamidine, radiotherapy }\end{array}$ & Survival & \\
\hline $\begin{array}{l}\text { Victor et al. (1958) case } 1 \\
\text { Odelberg-Johnson (1959) }\end{array}$ & $\begin{array}{l}45 \\
51\end{array}$ & $\begin{array}{l}\mathbf{F} \\
\mathbf{M}\end{array}$ & Lymphadenopathy & $\begin{array}{l}340 \\
100-200\end{array}$ & $\begin{array}{l}18 \text { months } \\
18 \text { months }\end{array}$ & $\begin{array}{l}\text { Cortisone, radiotherapy } \\
\text { Urethane }\end{array}$ & $\begin{array}{l}\text { Necropsy } \\
\text { Death }\end{array}$ & Yes \\
\hline $\begin{array}{l}\text { Aguayo et al. (1964) } \\
\text { Brain (1965) }\end{array}$ & 44 & $\begin{array}{l}\mathbf{M} \\
\mathbf{M}\end{array}$ & & 275 & 14 months & Cyclophosphamide & $\begin{array}{l}\text { Necropsy } \\
\text { Necropsy }\end{array}$ & Yes \\
\hline Murphy and Little (1966) & 58 & $\mathbf{F}$ & & 364 & 30 months & Cyclophosphamide & Necropsy & \\
\hline This report (case 4) & 40 & $\mathbf{M}$ & Lymphadenopathy & 236 & 27 months & $\begin{array}{l}\text { Cyclophosphamide, } \\
\text { methotrexate, busulphan, } \\
\text { prednisolone }\end{array}$ & Necropsy & \\
\hline $\begin{array}{l}\text { Osteolytic radiological features } \\
\text { Kurnick and Yolahem (1948) } \\
\text { case } 2\end{array}$ & 53 & $\mathbf{F}$ & & 'Normal' & 3 months & Stilbamidine & Not known & \\
\hline Victor et al. (1958) case 3 & 58 & $\mathbf{F}$ & & 45 & 14 months & Urethane & Necropsy & Yos \\
\hline Williams et al. (1959) case R. S. & 67 & $\mathbf{M}$ & & 225 & 21 months & 'Treatment for myeloma' & Necropsy & \\
\hline Furtado (1959) & 43 & $\mathbf{M}$ & & 'Normal' & 27 months & $\begin{array}{l}\text { Urethane, steroids, } \\
\text { radiotherapy }\end{array}$ & Survival & \\
\hline Ojea et al. (1961) & 47 & $\mathbf{F}$ & Splenomegaly & & 10 months & & Death & \\
\hline \multicolumn{9}{|l|}{ No radiological abnormality } \\
\hline Berlin (1946) & 64 & $\mathbf{M}$ & & 60 & 9 months & Priscol & Survival & \\
\hline Estes and Millikan (1954) & 43 & $\mathbf{F}$ & & 200 & 4 months & & Not known & \\
\hline Clarke (1956) & 66 & $\mathbf{M}$ & & 25 & 18 months & & Death & \\
\hline Victor et al. (1958) case 4 & 47 & $\mathbf{M}$ & & 222 & 10 years & $\begin{array}{l}\text { Urethane, stilbamidine, } \\
\text { radiotherapy }\end{array}$ & Survival & \\
\hline Boudin et al. (1961 and 1962) & 46 & $\mathbf{M}$ & Lymphadenopathy & 320 & 21 months & Steroids & Necropsy & Yes \\
\hline
\end{tabular}


TABLE II

\section{'SINGLE' MYELOMA WITH POLYRADICULONEUROPATHY}

\begin{tabular}{|c|c|c|c|c|c|c|c|c|c|}
\hline Series & Site & Age & Sex & $\begin{array}{l}\text { Reticuloendothel- } \\
\text { ial Abnormality }\end{array}$ & $\begin{array}{l}\text { C.S.F. } \\
\text { Protein }\end{array}$ & $\begin{array}{l}\text { Duration of } \\
\text { Neuropathy }\end{array}$ & Treatment & Fate & $\begin{array}{l}\text { Neuro- } \\
\text { pathology }\end{array}$ \\
\hline \multicolumn{10}{|c|}{ Osteosclerotic radiological features } \\
\hline Scheinker (1938) & Sternum & 39 & $\mathbf{M}$ & & 200 & 13 months & $\begin{array}{l}\text { Radiotherapy (to spine) } \\
\text { typhus vaccine }\end{array}$ & Necropsy & Yes \\
\hline Crow (1956) case 2 & Sternum & 67 & $\mathbf{F}$ & & 80 & 21 months & Radiotherapy (to sternum) & Survival & \\
\hline Small et al. (1961) & L2 vertebra & 41 & $\mathbf{M}$ & Splenomegaly (P.M.) & 224 & 6 months & & Necropsy & Yes \\
\hline Rushton (1965) & D11 vertebra & 45 & $\mathbf{M}$ & Splenomegaly (P.M.) & 240 & 21 months & Steroids & Necropsy & Yes \\
\hline This report (case 1) & Rib & 51 & $\mathbf{M}$ & Splenomegaly (P.M.) & 1,000 & 12 months & $\begin{array}{l}\text { Prednisolone, } \\
\text { 6-mercaptopurine }\end{array}$ & Necropsy & \\
\hline This report (case 3 ) & Acetabulum & 63 & $\mathbf{M}$ & Lymphadenopathy & 70 & 26 months & & Necropsy & \\
\hline \multicolumn{10}{|c|}{ Osteolytic radiological features } \\
\hline $\begin{array}{l}\text { Victor et al. (1958) } \\
\text { case } 2\end{array}$ & L1 vertebra & 48 & $\mathbf{M}$ & Lymphadenopathy & 90 & 10 months & & Necropsy & Yes \\
\hline $\begin{array}{l}\text { Rohmer et al. } \\
\text { (1962) }\end{array}$ & Rib & 34 & $\mathbf{M}$ & & 320 & 17 months & $\begin{array}{l}\text { T.A.B., strychnine, } \\
\text { intrathecal hydrocortisone, } \\
\text { radiotherapy (to rib) }\end{array}$ & Survival & \\
\hline $\begin{array}{l}\text { Gupta and } \\
\text { Prabhakar (1965) }\end{array}$ & Scapula & 35 & $\mathbf{M}$ & & 120 & 26 months & $\begin{array}{l}\text { Steroids, urethane, } \\
\text { radiotherapy }\end{array}$ & Survival & \\
\hline This report (case 2 ) & Acetabulum & 28 & $\mathbf{M}$ & & 500 & 6 years & $\begin{array}{l}\text { Prednisolone, radio- } \\
\text { therapy (to acetabulum) }\end{array}$ & Survival & \\
\hline
\end{tabular}

distal weakness in both legs, and impaired vibration and position senses in the feet. Stance and gait were unsteady. General examination was normal.

Over the next four months his disability worsened. The cerebrospinal fluid protein level (three examinations) ranged from $335 \mathrm{mg} . \%$ to $1,000 \mathrm{mg} . \%$, with no cells,

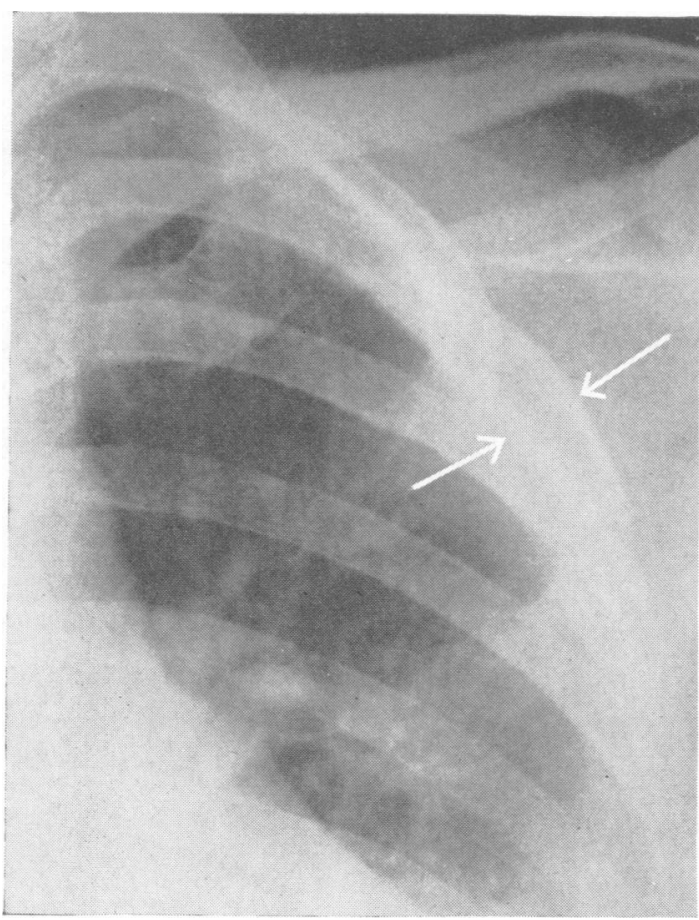

FIG. 1. Radiograph of left third rib (anterior view) showing localized expansion and thickening of the cortex (case 1). and without spinal block. A chest radiograph disclosed a localized sclerotic expansion of the left third rib (Fig.1). Haemoglobin was 17.4-18.9 g. \%, but peripheral blood examinations were normal. Bence-Jones protein was not present. Biopsy of the rib lesion was considered, but as this would have required formal thoracotomy in that site, this was not performed in view of the patient's poor condition and the uncertainty of any benefit he might derive. Despite being given A.C.T.H., over the next six months the neuropathy continued to worsen, and finger clubbing, peripheral cyanosis, and dependent oedema appeared. 6-Mercaptopurine was substituted; advice on radiotherapy was also sought, but the opinion was that this would not help. He died from pneumonia on 22 December 1965. The radiological appearance of the rib lesion remained unchanged throughout, and no other radiological lesion was detected.

At necropsy the left third rib was expanded by a brown fleshy mass. The sole abnormality in the spinal bone marrow was in the second lumbar vertebra where it was patchy yellow and red. The only histological abnormalities were in the rib, bone marrow, spinal cord, and brachial plexus. The bone marrow showed generalized hypoplasia, consistent with the effects of a cytotoxic drug. The rib tumour was composed of mature plasma cells, and contained dilated capillaries and sinuses. There was loss of bone within the lesion, but thickening of bone about it, with increased collagen tissue (Figs. 2 and 3). Unfortunately peripheral nerve was not examined, and the sections from the spinal cord and brachial plexus were inadequate; they showed only minor nonspecific changes, without evidence of myelomatous infiltration.

CASE 2 (PETER MCCALLUM CLINIC No. 60/11/2098) D.S.H., a 28-year-old salesman, noticed pain in the right hip with vague weakness in April 1960. After three months both legs had become so weak that he could not walk; there were numbness and paraesthesiae in all extremities. 


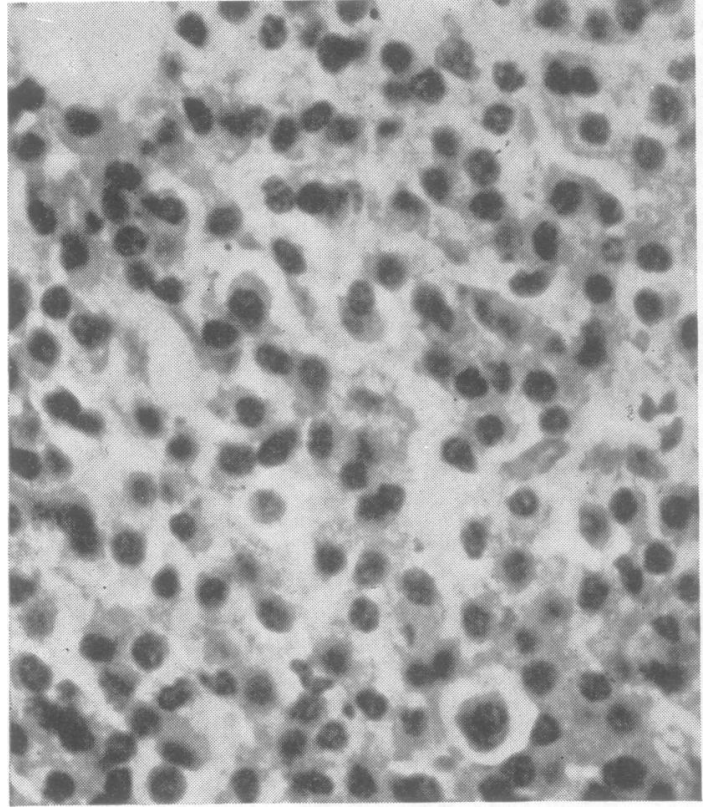

FIG. 2. Plasmacytoma of left third rib (case 1). Haematoxylin and eosin $\times 400$.

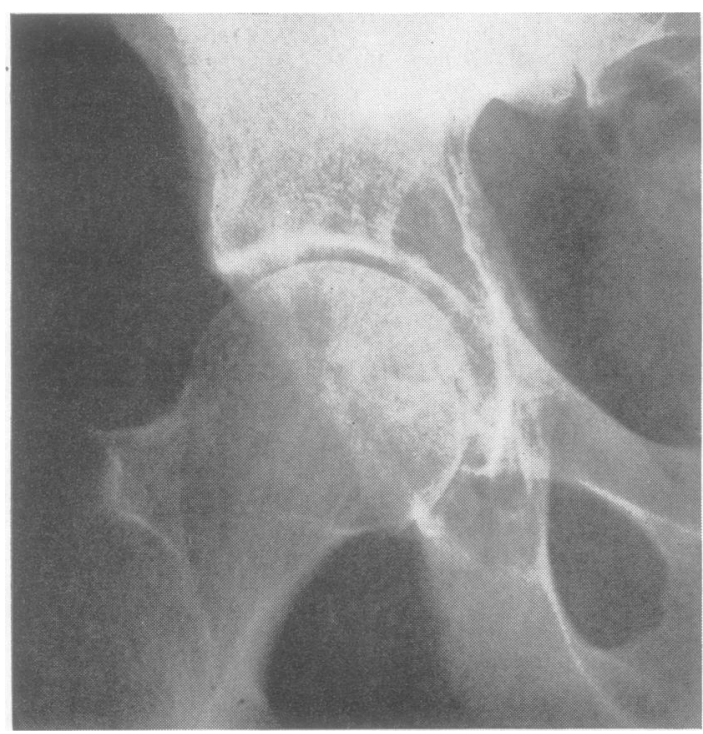

FIG. 4. Radiograph of right hip (anterior view) showing localized osteolytic lesion in the acetabular region (case 2).

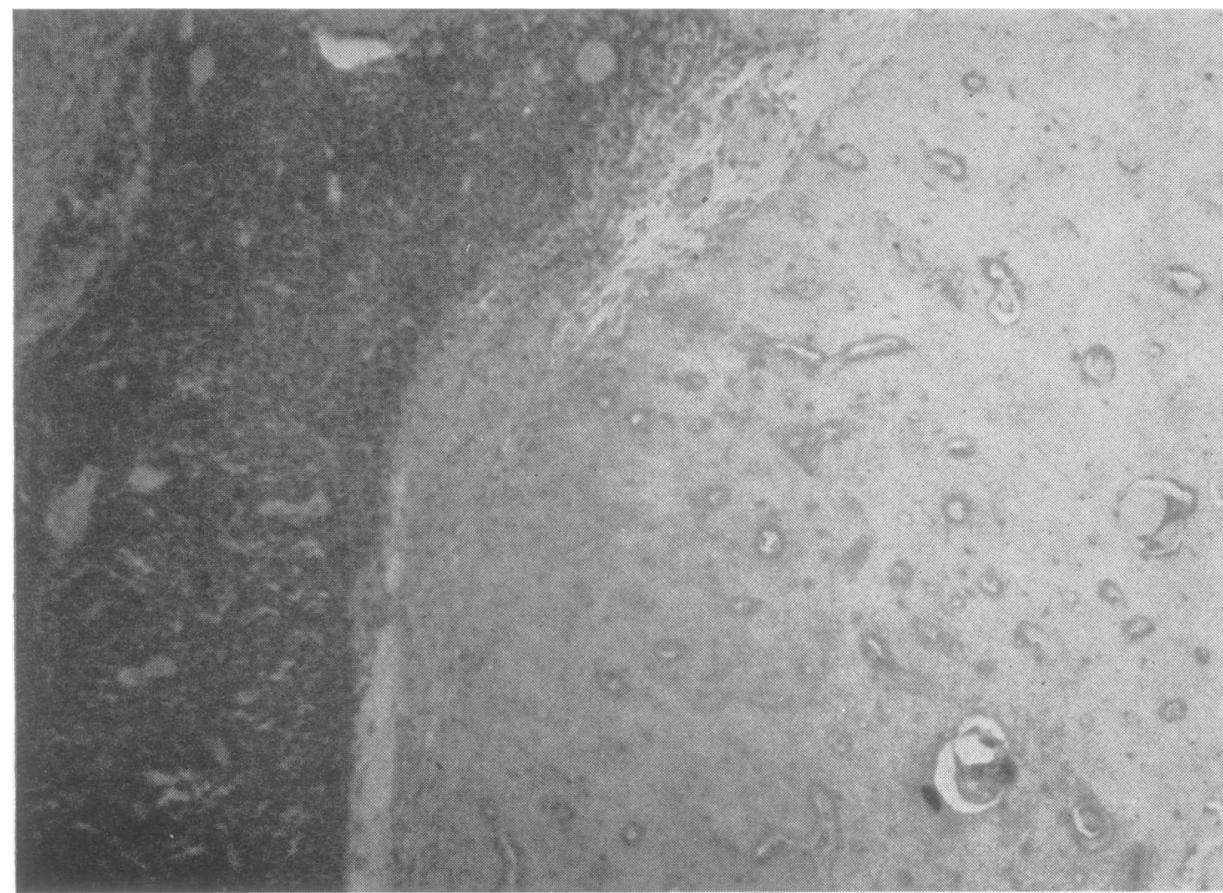

FIG. 3. Bone at periphery of plasmacytoma (case 1).

Haematoxylin and eosin $\times 50$. 


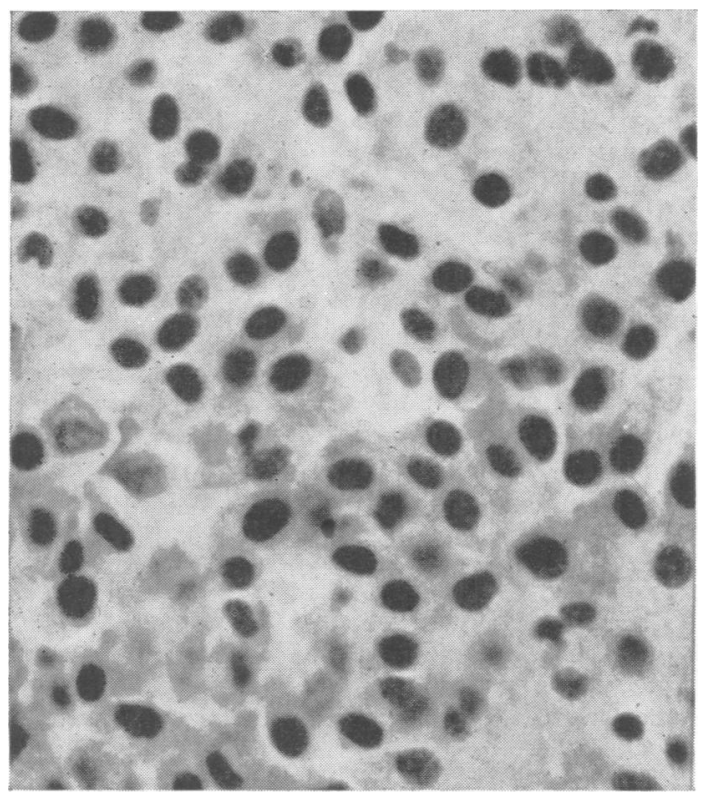

FIG. 5. Biopsy of right acetabulum (case 2). Haematoxylin and eosin $\times 400$.

Radiographs of the pelvis revealed an osteolytic area in the right acetabulum (Fig. 4) and biofsy of this area showed sheets of mature plasma cells (Fig. 5) in which were many small arteries and dilated sinuses. There was no bone within the tumour, but that adjacent to it was increased in thickness.

When seen there was mild wasting and weakness of the hands but gross weakness of the legs and trunk. Calf muscles were tender. All deep reflexes were absent. The only sensory change was in the legs where position and vibration senses were moderately impaired. Cerebrospinal fluid protein level was $500 \mathrm{mg} . \%$, with no significant cells and normal manometry. Bone marrow biopsy disclosed a $7 \%$ increase in plasma cells, many having abnormally pale nuclei and irregular shapes. Four studies of the serum proteins by electrophoresis demonstrated persistent elevation of alpha 2 globulins and an abnormal gamma globulin. No Bence-Jones protein was detected.

On 5 October 1960 radiotherapy was commenced, 3,000 rads being delivered to the right hip in three weeks. By January 1961 the neuropathy was improving and the patient was walking with assistance. In June 1966 this improvement was maintained. There was still no voluntary movement of the feet, but there was only mild weakness of knee movements. Joint position and vibration senses were mildly impaired at the toes but other sensory modalities were intact. Cyanosis and oedema persisted in the legs The upper limbs were normal. Radiographs of the pelvis showed a lytic area in the ischium with a sclerotic margin, consistent with a slowly growing myelomatous deposit. On serum protein electrophoresis the trace of abnormal gamma globulin was the only abnormality. Serum protein immunoelectrophoresis showed a small amount of myeloma type protein in the $\mathrm{IgG}$ fraction. The patient refused permission for repeat lumbar puncture or hip biopsy.

CASE 3 (ALFRED hOSPITAL No. 33088) D.K.F., a 63-yearold male brewery worker, was admitted on 16 December 1959 because of a mass in the right iliac fossa. He described pain and weakness of the legs for three months, with painless Raynaud's phenomena. He had lost weight. Examination disclosed normal power in the legs but sluggish deep reflexes. The only sensory change was impaired cutaneous sensation in the feet.

At laparotomy the mass consisted of matted lymph nodes overlying the lateral pelvic wall. Biopsy demonstrated large numbers of plasma cells, many of which were bizarre in shape, pale staining, and with a loose chromatin network (Fig. 6). Peripheral blood examination disclosed Hb 18.2-19.0 g. \%, W.B.C.s 11,000-13,000/ c.mm., affecting all cell types. The only serum protein electrophoretic abnormality was a raised beta 2 globulin level. There was no Bence-Jones protein in the urine. Sternal marrow aspiration was normal. The cerebrospinal fluid contained $70 \mathrm{mg} . \%$ of protein with $3 \mathrm{lym}$ phocytes/c.mm. and a normal Queckenstedt response. Radiographs of the pelvis showed a sclerotic area in the right acetabulum (Fig. 7). The patient then recalled having had a radiograph of the right hip three years before which had been 'abnormal'.

Over the next four months his weakness progressed. Peripheral cyanosis appeared and there was early finger clubbing. Neurological abnormalities were confined to

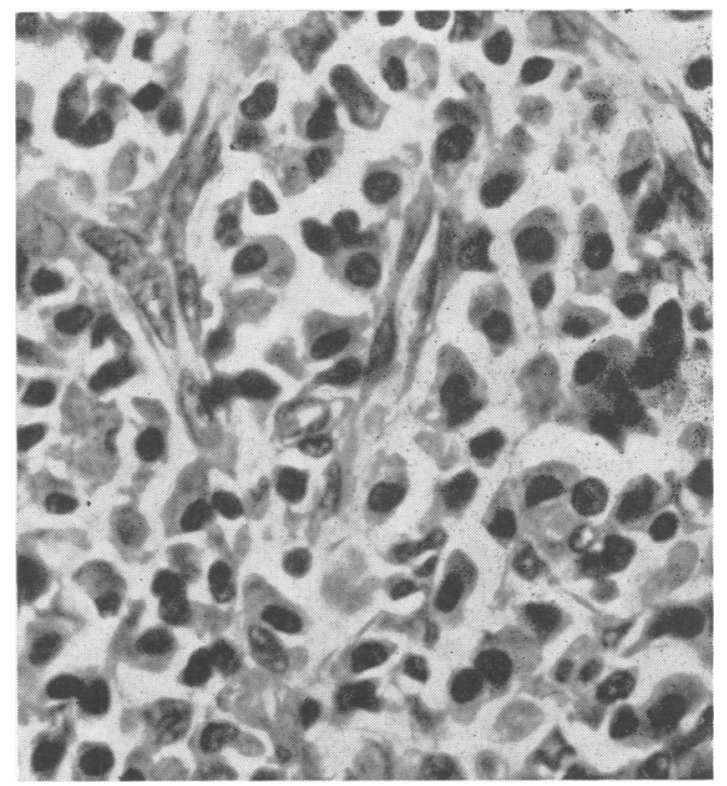

FIG. 6. Lymph node biopsy (case 3). Haematoxylin and eosin $\times 400$. 


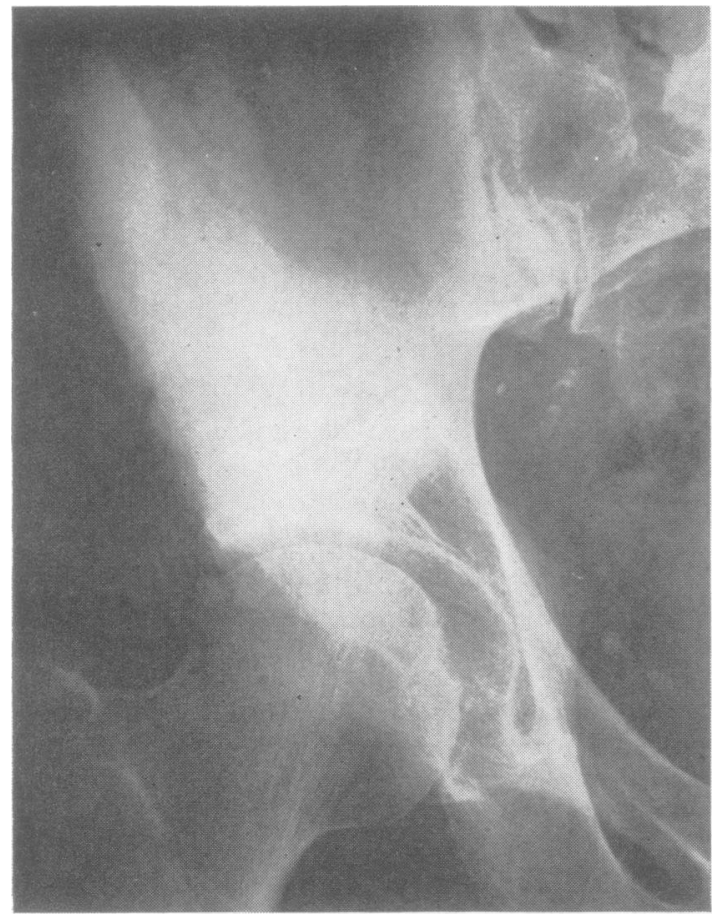

the legs, with distal wasting and weakness, absent tendon reflexes, and impairment of the senses of light touch, pain, and temperature below the knees. On sural nerve biopsy (Figs. 8 and 9) the nerve fibres showed an increase in fibrous connective tissue with occasional lymphoyctic perivascular infiltrates and slight thickening of vessel walls. Iliac crest biopsy demonstrated many mature plasma cells; in some areas the bone was grossly thickened.

He died on 12 January 1961, and at necropsy there were enlarged, hard, pale lymph nodes along the right common iliac artery. Axillary and inguinal glands were mildly enlarged. The spinal bone marrow was normal but the right ilium was distended by a dense mass of pale bone. The only significant histological changes were in the lymph nodes and the right ilium, being similar to those seen at biopsy. Unfortunately no neuropathological sections were taken.

CASE 4 W.C.J., a 40-year-old male, was seen in March 1964. Five months earlier he had noticed pain in his left foot, which spread to the muscles of the limbs and trunk; for the last two months he had had weakness in the shoulders, trunk, and legs. He had lost 2 stones in

FIG. 7. Radiograph of right hip (anterior view) showing extensive sclerosis involving the acetabulum and ilium (case 3).

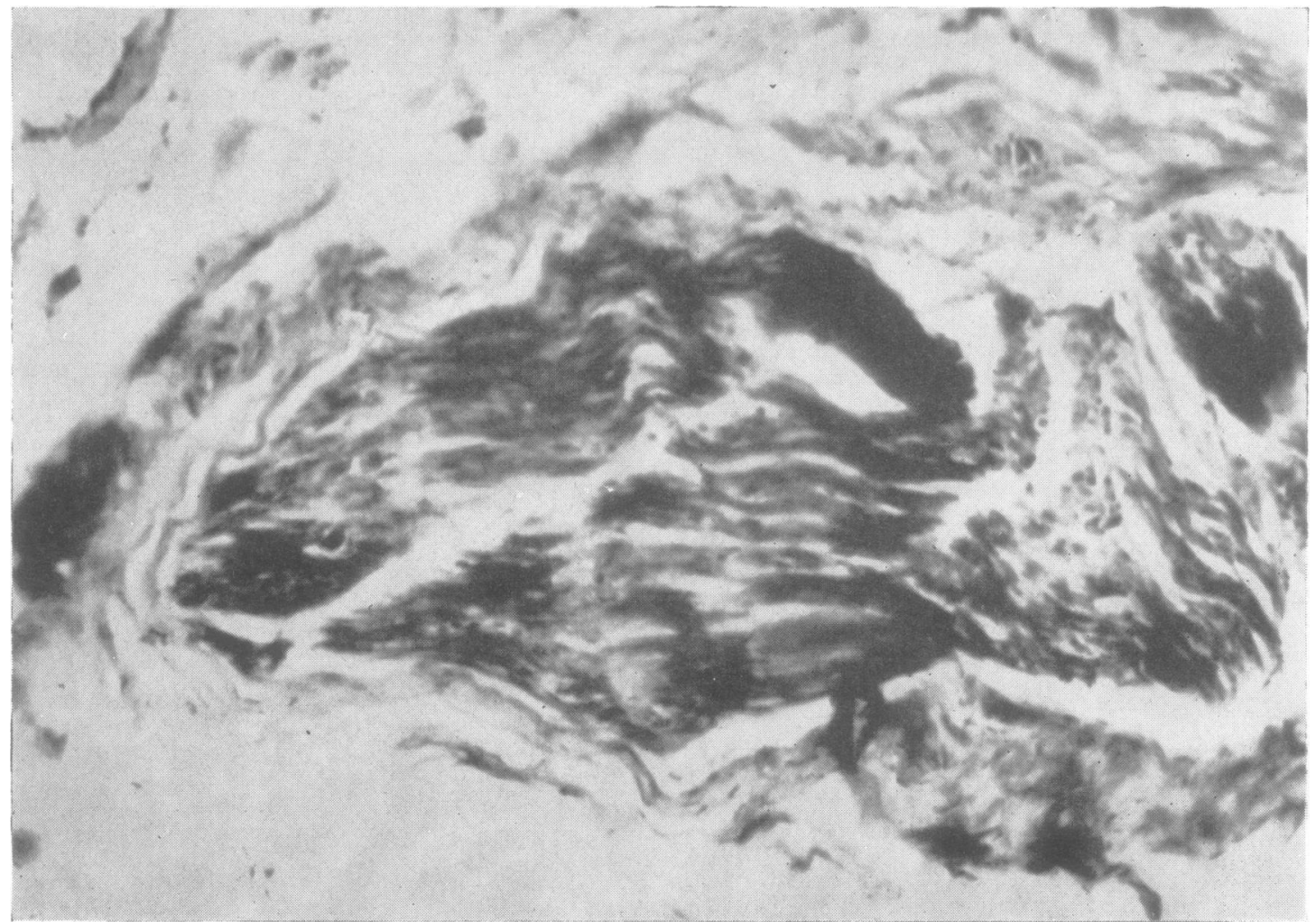

FIG 8. Sural nerve biopsy showing increased fibrous connective tissue (case 3). Picro-Gomori $\times 70$. 


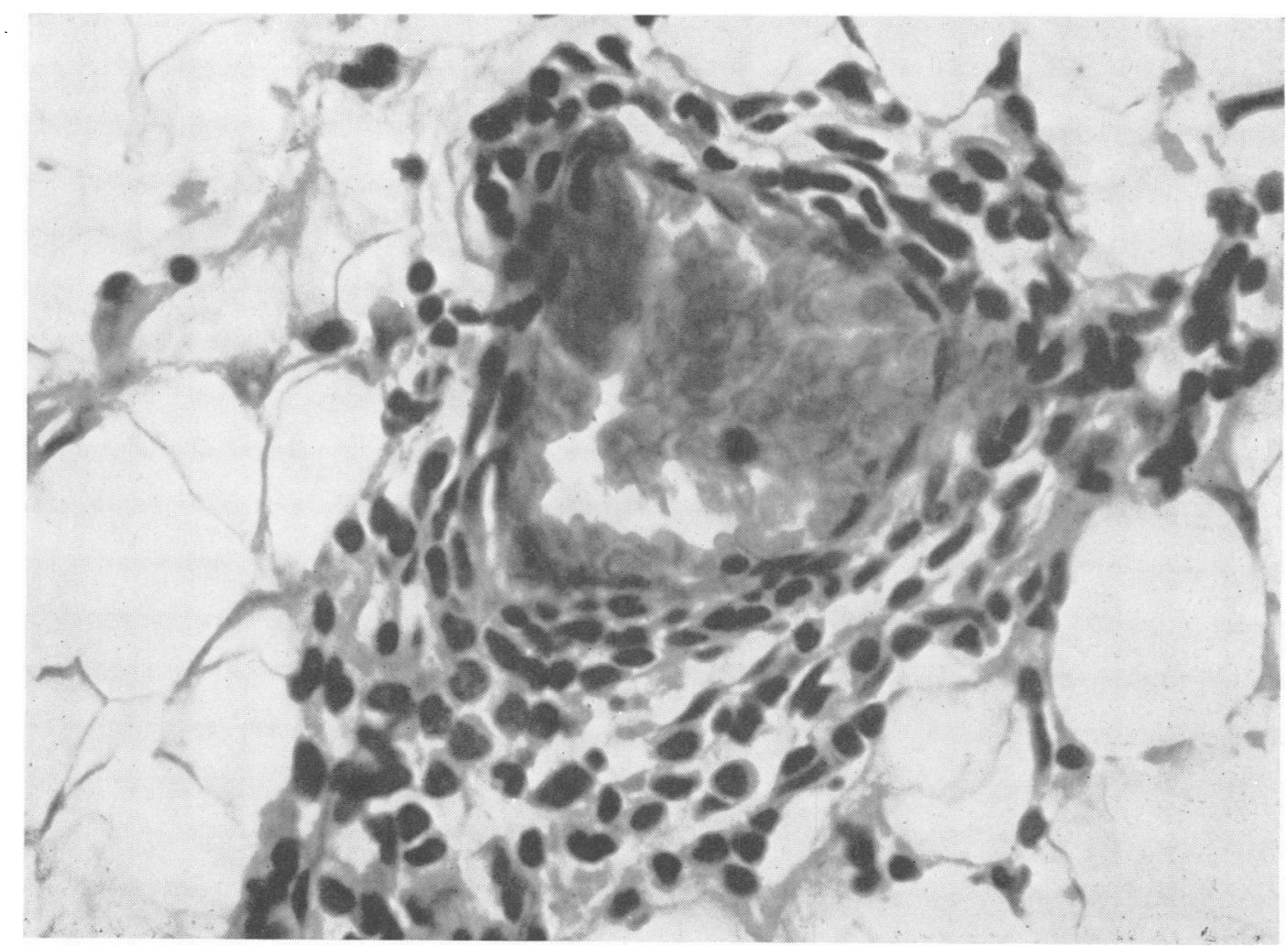

FIG. 9. Sural nerve biopsy, showing mononuclear cell perivascular infiltration (case 3). Haematoxylin and eosin $\times 240$.

weight. Examination revealed a moderate weakness, proximal in the arms, generalized in the legs. There was widespread muscle tenderness. Tendon reflexes were absent but the only sensory change was lack of vibration perception at the ankles. The cerebrospinal fluid contained $235 \mathrm{mg}$. \% protein, 10 lymphocytes/c.mm., but manometry was normal. Haemoglobin, the differential W.B.C. and E.S.R. were normal. A skeletal radiological survey showed wide spread multiple small dense areas (Fig. 10), but in the right pubic bone was a large lytic lesion (Fig. 11), biopsy of which revealed myeloma (Fig. 12). Iliac crest biopsy showed no abnormality, but there was a mild increase in plasma cells on sternal marrow aspiration. Urine examinations for Bence-Jones protein were negative. Serum protein electrophoresis showed a reduced albumin level (3.3 g.\%) and increased alpha and gamma globulins. He was considered to be suffering from multiple myeloma complicated by chronic polyneuropathy. However, a further opinion on the histology suggested the possibility of carcinoma of undifferentiated type, and accordingly a course of cyclophosphamide was commenced.

Within weeks ascites, oedema, and proteinuria developed. The neuropathy had advanced further. On repeat radiographs there was 'an increase in the number and density of the sclerotic nodules and the pubic lesion has progressed. The latter could be a plasmacytoma and the multiple lesions in the rest of the skeleton are the rare sclerosing type of multiple myeloma.'

Gradual deterioration continued over the next 14 months with further weight loss, increasing oedema, ascites, and anaemia. The skin became pigmented and thickened and prominent axillary lymphadenopathy appeared. He was treated variously with methotrexate, busulphan, and prednisolone, until he died in January 1966.

At necropsy the spleen was greatly enlarged and there was an increase in retroperitoneal fat which was hard in consistency. Sections were taken from this fatty tissue, para-aortic lymph nodes, spleen, lung, liver, heart, and pancreas. No neuropathological specimens were obtained. The only microscopic findings were in the lymph nodes, fatty tissue, and spleen, numerous plasma cells appearing in each. The original pubic bone biopsy (Fig. 12) was reviewed and the changes were considered consistent with myeloma.

\section{REVIEW OF THE LITERATURE}

CLINICAL FEATURES The 27 patients reviewed here, including the four described in this report, each 
had a symmetrical, slowly progressive, sensorimotor polyneuropathy which commenced in the lower limbs. In 20 cases the cerebrospinal fluid contained no significant cells but the protein level was raised; in 14 the rise exceeded $200 \mathrm{mg} . \%$, higher than explicable by the myeloma alone (Madonick and Solomon, 1953). These criteria are generally consistent with those of the Landry-Guillain-Barré syndrome (Wiederholt, Mulder, and Lambert, 1964).

There was a clear male preponderance (20:7), with a peak age incidence of 35 to 55 years (16 cases) (Tables I and II). In the later stages there was sometimes peripheral cyanosis, finger clubbing, or oedema

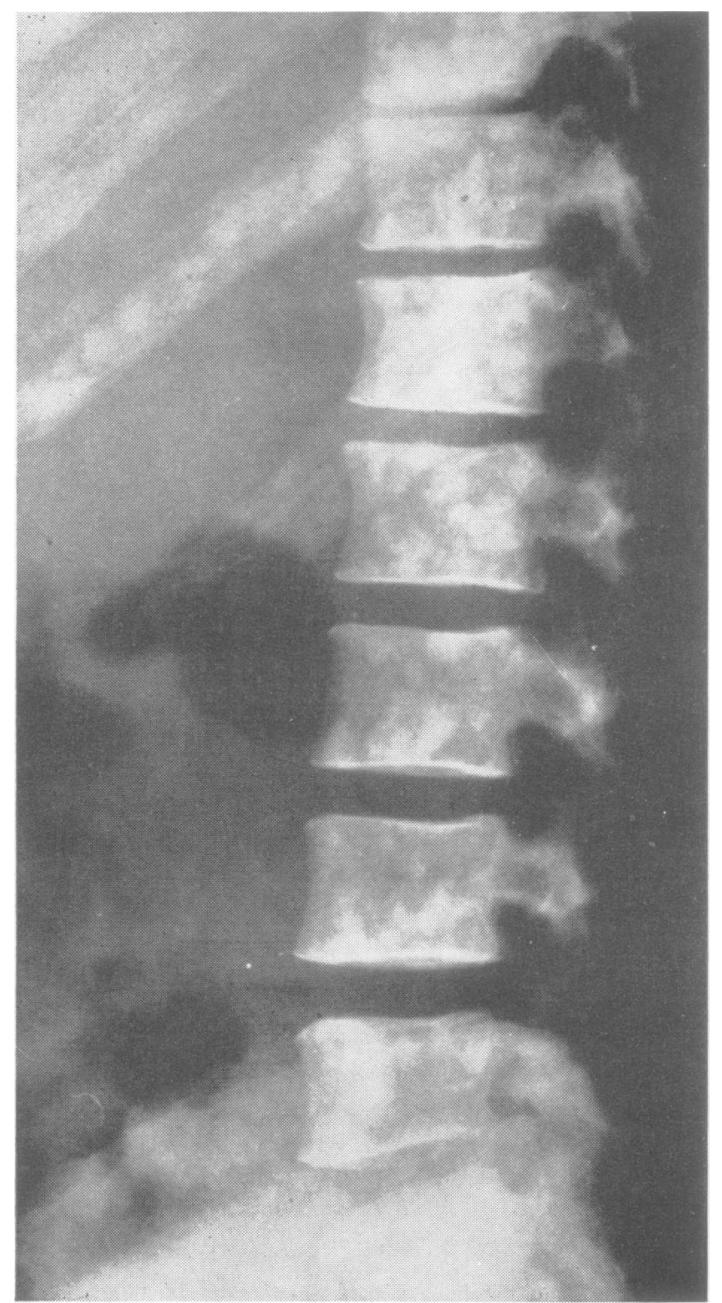

FIG. 10. Radiograph of lumbar spine (lateral view) showing multiple dense areas throughout the vertebrae and ribs (case 4).
(Crow, 1956; Gupta and Prabhakar, 1965; this report). Most striking of all, as Victor et al. (1958) point out, there may be no correlation between the severity of the neuropathy and the extent of the myeloma. The neuropathy usually progressed relentlessly to death within two years. We suggest that a protracted polyradiculoneuropathy, especially in a middle-aged man, should arouse suspicion of myeloma as the cause.

INVESTIGATIONS The outstanding radiological feature is the frequency of the rare osteosclerotic form of the myeloma (13 cases, Tables I and II). Furthermore 10 patients had the uncommon 'single' form of myeloma (Table II). We note that in four cases (Furtado, 1959; Brain, 1965; Murphy and Little, 1966; and case 3 of this report) the radiological abnormality was probably present some time before the onset of the polyneuropathy.

These uncommon radiological forms of myeloma might be sought in any chronic progressive polyneuropathy of the Landry-Guillain-Barré type. However, it is equally important to pursue myeloma even without these changes, for in five patients in this review no radiological abnormality was found (Table I).

Other investigations show little of significance.

Peripheral blood examinations There was no characteristic haematological abnormality. In cases 1 and 3 of this report the $\mathrm{Hb}$ level reached 18.9 and 19.0 g. \% respectively, and Ojea, Ucha Udabe, and Carmena (1961) reported polycythaemia vera in

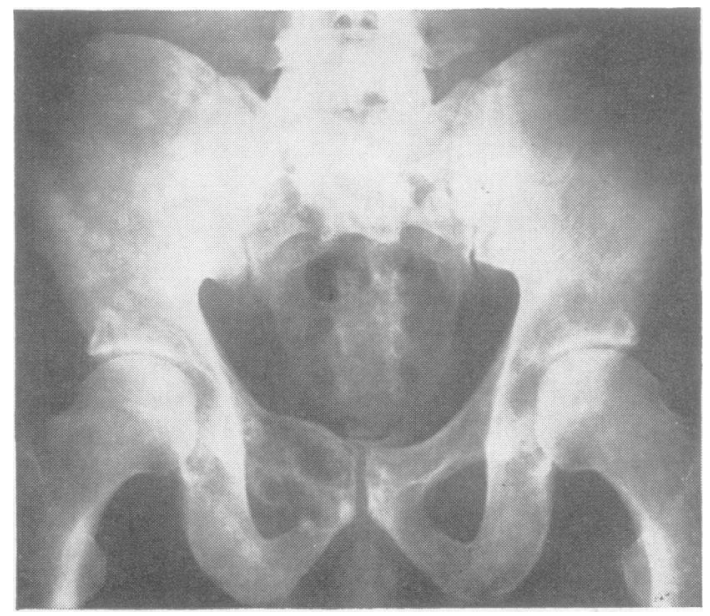

FIG. 11. Radiograph of pelvis (anterior view) showing multiple dense areas, with an expanding osteolytic lesion in the right pubis (case 4). 
their patient. In 15 patients in whom the E.S.R. is recorded only five showed an elevated E.S.R. in the earlie stages of the illness; three of these had multiple myeloma without radiological changes.

Bone marrow biopsy This was positive in 13 of the 21 patients in whom it was performed.

Serum protein electrophoresis On paper electrophoresis there was no consistent outstanding abnormality. In four patients immunoelectrophoresis was performed, and in each an abnormal gamma globulin was found.

Other protein disturbances In six patients macroglobulins were sought, and found in two. Four patients had serum examinations for cryoglobulins, two being positive. Eighteen patients had urine examinations for Bence-Jones protein; these were negative in all patients with 'single' myeloma, and positive in six of the 12 patients with multiple myeloma who were examined.

Thus the only characteristic abnormalities are the $x$-ray changes, and even these are not always present (Table I). For diagnosis, repeated bone marrow biopsy and serum protein immunoelectrophoresis may be valuable.
PROGNOSIS AND TREATMENT Of 25 patients whose fate is known, only eight survived (Tables I and II), and seven of them were improved by treating the myeloma, especially with radiotherapy (Tables I and II). Radiotherapy to the lesion was not employed in any of the fatal 'single' myeloma cases and was used in only one fatal case of multiple myeloma. We note that experience with steroids was discouraging (Tables I and II).

The reversibility of this otherwise fatal polyradiculoneuropathy applies particularly to the localized myeloma, to which radiotherapy might be specifically directed. Where 'single' myeloma is surgically accessible, the lesion might be resected with yet higher hopes. We have regretted that our knowledge of the fate of our case 2 was not obtained until after the death of W. E. W. (case 1), for despite our misgivings, this would have persuaded us to submit W. E. W. to radiotherapy, if not to rib resection.

PATHOLCGY Descriptions of the neuropathology are provided by previous authors (Tables I and II). There is no significant change in the brain, cere-

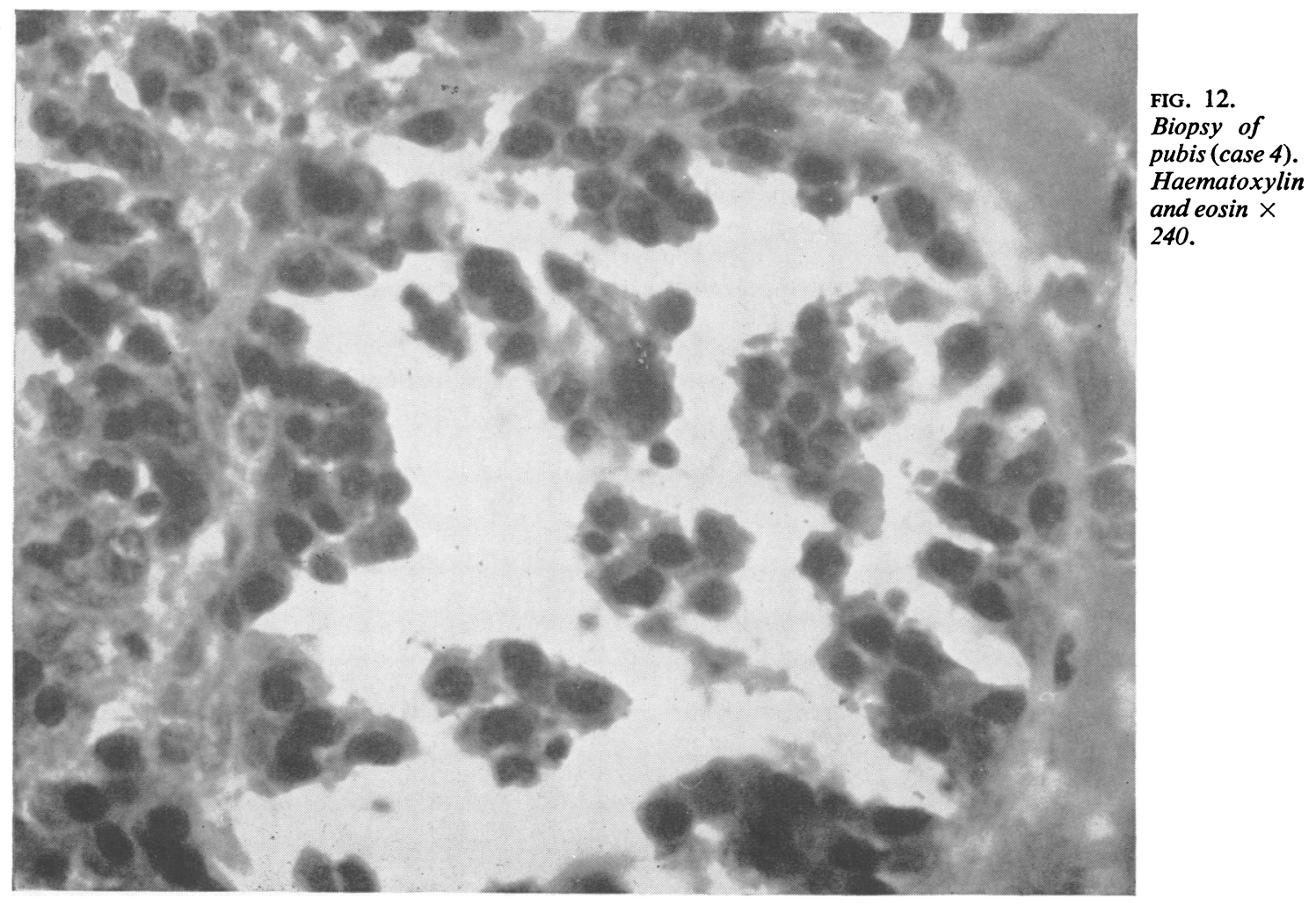


bellum, or brainstem. The changes consist of myelin fragmentation and macrophage invasion in the peripheral nerves and spinal roots, chromatolysis of anterior horn cells and dorsal root ganglia, and variable gliosis and demyelination in the posterior columns of the spinal cord. Amyloid and myelomatous infiltration are not present. These changes are accepted as being identical to those of carcinomatous mixed sensory-motor neuropathy (Victor et al., 1958; Small et al., 1961; Simpson, 1962; Rushton, 1965).

The histology of the osteosclerosis is described briefly by Victor et al. (1958), Aguayo et al. (1964), Rushton (1965), and in our case 1. There was dense new bone formation in the intertrabecular spaces accompanied by increased reticulin surrounding the myeloma and loss of bone within the lesion. The radiologically lytic lesion of our case 2 also showed this histological picture.

\section{DISCUSSION}

RELATIONSHIP OF POLYRADICULONEUROPATHY TO MYELOMA The relationship to myeloma appears indisputable by its response to treatment of the myeloma.

The unusual radiological characteristics have been stressed. It may be either localized (or 'single'), or osteosclerotic, itself either single or multiple. Particularly uncommon is the osteosclerotic myeloma, of which we could find only 33 examples in the literature (Tables I and II; Bibliography ${ }^{13-28}$ ); yet 13 of these cases were complicated by this neuropathy. Attention has already been drawn to the sclerosis by Small et al. (1964). We cannot say whether the sclerosis is that seen with 'myeloproliferative' disorders (Videbaek, 1956; Brody, Beizer, and Schwartz, 1964), whether new bone is formed by the myeloma (Kinare, Parulkar, Panday, and Sen, 1965), or whether it is merely a non-specific bone reaction. The interesting fact is that when LandryGuillain-Barré polyneuropathy complicates myeloma, 'typical' myeloma is unusual.

RELATIONSHIP TO NEUROPATHIES OF OTHER MALIGNANT DISEASE Like previous authors we are impressed by the clinical similarities of the sensorimotor polyneuropathies of myeloma and carcinoma. There is the same protracted course and the same incomplete correlation between the severities of the neoplasm and the neuropathy. Both forms show similar age peak incidence and male predominance, and Brain and Henson (1958) comment on the characteristically raised protein level in the cerebrospinal fluid without increase in cells in carcinomatous mixed polyneuropathy. Furthermore, as men- tioned above, the pathologies are the same. We also note that a sensory neuropathy similar to that of carcinoma has been described with myeloma (Victor et al., 1958, case 5).

Our impression is that the sensorimotor polyneuropathies of carcinoma and myeloma are similar if not identical, and have similar pathogeneses. Therefore, since radiotherapy seems to be of value in myelomatous mixed polyneuropathy, it may be of use in its carcinomatous counterpart.

ROLE OF DISTURBED IMMUNOLOGICAL MECHANISMS The pathogenesis of myelomatous polyradiculoneuropathy has provoked much conjecture. Cachexia and malnutrition do not account for such cases in which the myeloma remains localized. Berlin (1946) suggested that abnormal serum proteins slowed capillary flow in the nutritional vessels of the nerves, but this hypothesis leaves unexplained the rarity of the neuropathy despite the frequency of these protein abnormalities, and its occurence when these proteins cannot be detected. Myelomatous infiltration of nerves occurs (e.g., Barron et al., 1960), but was not found in a number of the cases in this review, despite careful search. A 'toxin' might be responsible, but its nature would be uncertain.

Paramyloid deposition in peripheral nervous tissue must also be considered. This was not seen in these cases, but it remains a theoretical possibility. However, Victor et al. (1958) point out that in none of the reported cases of amyloid neuropathy was multiple myeloma associated, and find that this suggestion lacks pathological confirmation.

Simpson (1962) reviews the neuropathies, and enlarges the concept of disturbance of protein metabolism in myeloma. Abnormal macroglobulins occur not only in the primary macroglobulinaemia of Waldenström, but also in secondary macroglobulinaemias, including those accompanying neoplasms, such as bronchial carcinoma, and those with myeloma, reticulosis, 'collagen' disorder, and amyloidosis; polyneuropathy may complicate any of these. He suggests that with the serum protein disorder arising from the reticuloendothelial cells there may also be abnormal parenchymatous protein metabolism, perhaps affecting peripheral nervous tissue.

It is probable that the Landry-Guillain-Barré syndrome results from immunological disorder, a theory which has been reviewed by Miller (1957) and Simpson (1962), and Melnick (1963) has contributed a further study. The classical experimental studies by Waksman and Adams $(1955,1956)$ lend further support to this theory.

It is now accepted that in myeloma the plasma cells produce the immunoglobulins or antibodies 
(Nossal, 1965; Kunkel, 1965). As experimental myeloma progresses there emerges one particular strain of cells (Potter, 1962); this situation may well occur in man (Bachmann, 1965). Waldenström, Winblad, Hällén, and Liungman (1964) found that myelomatous plasma cells continue to form the same pattern of immunoglobulins as their ancestral plasma cells, and there sometimes results the production in great amount of one 'specific' antibody without an inducing antigen. In this way antibodies may well be formed that react against peripheral nervous tissue components to cause a progressive polyneuropathy. Presumably the osteosclerotic propensity might be coupled with this production of antibodies 'specific' to peripheral nerve constituents. This theory would be consistent with the occurrence of neuropathy even with a small plasmacytoma, and with its arrest or reversibility with radiotherapy. These antibodies could be equivalent to the 'toxins' postulated by earlier writers, and also represent a form of abnormal protein metabolism as proposed by Simpson (1962).

There is evidence of circulating antibody to nervous tissue in carcinomatous sensory neuropathy (Wilkinson, 1964; Croft, Henson, Urich, and Wilkinson, 1965; Wilkinson and Zeromski, 1965; Alvord, 1965). However, antibodies are yet to be found in the mixed polyneuropathies, either carcinomatous or myelomatous, and the evidence for them being due to immunological disturbance remains at the best circumstantial. Nevertheless this has the attraction of a unifying concept, linking acute 'infective' polyneuritis on one hand, the neuropathies of the collagen diseases on another, and those of carcinoma, myeloma, and perhaps the reticuloses on another.

\section{SUMMARY}

Four further cases are described and the literature is reviewed of the association of a chronic polyradiculoneuropathy with myeloma, 27 cases in all.

This study establishes an earlier suggestion that there is a very significant association of the rare osteosclerotic form of myeloma with this chronic polyradiculoneuropathy. It also shows that this otherwise fatal polyradiculoneuropathy is reversible by treatment specific for myeloma, particularly radiotherapy.

The relationship of this polyradiculoneuropathy to that sometimes seen with other malignancies is discussed, and its pathogenesis with reference to possible disturbance of immunological mechanisms.

It is a pleasure to acknowledge the help of Dr. K. J. Murphy and Dr. J. H. Little who kindly provided us with information about their patient to include in the tables. Dr. M. Drake and Dr. D. Forster of the Pathology Department, Prince Henry's Hospital, examined the histological sections. Dr. M. Drake, Mr. J. Scrimegeour of the Prince Henry's Hospital Photography Department, and Mr. R. Wilson of the Mont Park Neurosurgical unit X-ray Department prepared the photographs. Dr. G. Goldstein, of the Walter and Eliza Hall Institute, advised us regarding myeloma and disturbed immunology. The Medical Superintendent of Prince Henry's Hospital, the Medical Director of the Peter McCallum Clinic, the Medical Committee of the Alfred Hospital, and the Chairman of the Repatriation Department of Victoria, gave permission for use of their respective Hospital's records in the case presentations. The Librarians of the A.M.A. Library, Melbourne, and the Peter McCallum Clinic, Melbourne, gave valuable assistance in the collection of our references.

\section{REFERENCES}

Aguayo, A., Thompson, D. W., and Humphrey, J. G. (1964). Multiple myeloma with polyneuropathy and osteosclerotic lesions. J. Neurol. Neurosurg. Psychiat., 27, 562-566.

Alvord, E. C. (1965). Brain antigens and antibodies: The possible relationship between carcinomatous and experimental allergic neuroencephalomyelitides. In The Remote Effects of Cancer on the Nervous System, edited by Lord Brain and F. H. Norris, pp. 188-203. Grune and Stratton, New York and London.

Bachmann, R. (1965). Simultaneous occurrence of two immunologically different M-components in serum. Acta med. scand., 177, 593-599.

Barron, K. D., Rowland, L. P., and Zimmerman, H. M. (1960). Neuropathy with malignant tumor metastases. J. nerv. ment. Dis., 131, 10-31.

Berlin, R. (1946). A case of myeloma with symptoms from the nervous system. Acta med. scand., suppl. 170, 156-168.

Boudin, G., Pépin, B., and Brion, S. (1961). Neuropathie périphérique dégénerative et myélome (observation anatomo-clinique). Bull. Soc. med. Hôp. Paris, 77, 490-500.

-_, - _ - Labet, R., Lauras, A., and Lyon, G. (1962). Affoctions malignes et neuropathies dégénératives. A propos de 4 observations anatomo-cliniques. Presse med., 70, 977-980.

Brain, R. (1965). In The Remote Effects of Cancer on the Nervous System, edited by Lord Brain and F. H. Norris, p. 164. Grune and Stratton, New York and London. Also cited by Aguayo et. al. (1964)

_- and Henson, R. A. (1958). Neurological syndromes associated with carcinoma. Lancet, 2, 971-975.

Brody, J. I., Beizer, L. H., and Schwartz, S. (1964). Multiple myeloma and the myeloproliferative syndromes. Amer. J. Med., 36, 315-319.

Clarke, E. (1956). Peripheral neuropathy associated with multiple myelomatosis. Neurology (Minneap.), 6, 146-151.

Croft, P. B., Henson, R. A., Urich, H., and Wilkinson, P. C. (1965) Sensory neuropathy with bronchial carcinoma: a study of four cases showing serological abnormalities. Brain, 88, 501514.

Crow, R. S. (1956). Peripheral neuritis in myelomatosis. Brit. med. J., 2, 802-804.

Estes, H. R., and Millikan, C. H. (1954). Polyneuritis and radiculitis associated with multiple myeloma: report of a case. Proc. Mayo Clin., 29, 453-455.

Furtado, D. (1959). Plasmacytoma and peripheral neuropathy. J. med. (Porto), 40, 565-572.

Gupta, S. P., and Prabhakar, B. R. (1965). Peripheral neuropathy and solitary myeloma. Brit. med. J., 2, 1004.

Kinare, S. G., Parulkar, G. B., Panday, S. T., and Sen, P. K. (1965) Extensive ossification in a pulmonary plasmacytoma. Thorax, 20, 206-210.

Kunkel, H. G. (1965). Myeloma proteins and antibodies. Amer. J. Med., 39, 1-3.

Kurnick, N. B., and Yolahem, S. B. (1948). Peripheral neuritis complicating multiple myeloma. Arch. Neurol. Psychiat. (Chic.), 59 378-384. 
Madonick, M. J., and Solomon, S. (1953). Total protein content of cerebrospinal fluid in multiple myeloma. Neurology (Minneap.), 3, 369-374.

Melnick, S. C. (1963). Thirty-eight cases of the Guillain-Barré syndrome: an immunological study. Brit. med. J., 1, 368-373.

Miller, H. (1957). Clinical manifestations of tissue reaction in the nervous system. In Modern Trends in Neurology, (Second Series), edited by D. Williams, pp. 164-176. Butterworths, London.

Murphy, K. J., and Little, J. H. (1966). Personal communication.

Nossal, G. J. V. (1965). The mechanism of action of antigen. Austr. Ann. Med., 14, 321-328.

Odelberg-Johnson, O. (1959). Osteosclerotic changes in myelomatosis: report of a case. Acta radiol. (Stockh.), 52, 139-144.

Ojea, M., Ucha Udabe, R., and Carmena, A. (1961). Poliglobulia y polineuritis en el curso de un mieloma. Prensa méd. argent., 48, 1457-1460.

Potter, M. (1962). Plasma cell neoplasia in a single host: a mosaic of different protein-producing cell types. J. exp. Med., 115, 339-356.

Rohmer, F., Mengus, M., and Buchheit, F. (1962). Neuropathie paranéoplasique à type de syndrome de Guillain-Barré chez un malade atteint de myélome solitaire. Rev. Oto-neuro-ophtal., 34, 97-107.

Rushton, D. I. (1965). Peripheral sensorimotor neuropathy associated with a localized myeloma. Brit. med. J., 2, 203-205.

Scheinker, I. (1938). Myelom und Net vensystem. Uber eine bisher nicht beschriebene mit eigentümlichen Hautveränderungen einhergehende Polyneuritis bei einem plasmazellulären Myelom des Sternums. Dtsch. Z. Nervenheilk., 147, 247-273.

Simpson, J. A. (1962). The neuropathies. In Modern Trends in Neurology. Series 3, edited by D. Williams, pp. 245-291. Butterworths, London.

Small, J. M., Moxon, C. P., and Woolf, A. L. (1961). Report on a clinicopathological conference. Bgham med. Rev., 20, 546-552.

Victor, M., Banker, B. Q., and Adams, R. D. (1958). The neuropathy of multıple myeloma. J. Neurol. Neurosurg. Psychiat., 21 , 73-88.

Waksman, B. H., and Adams, R. D. (1955). Allergic neuritis: an experimental disease of rabbits induced by the injection of peripheral nervous tissue and adjuvants. J. exp. Med., 102, 213-236.

_- (1956). Symposium on peripheral neuropathies; a comparitive study of experimental allergic neuritis in the rabbit, guinea pig, and mouse. J. Neuropath. exp. Neurol., 15, 293-333.

Waldenström, J., Winblad, S., Hällén, J., and Liungman, S. (1964). The occurrence of serological 'antibody' reagins or similar gammaglobulins in conditions with monoclonal hypergammaglobulinemia, such as myeloma, macroglobulinemia, etc. Acta med. scand., 176, 619-631.

Wiederholt, W. C., Mulder, D. W., and Lambert, E. H. (1964). The Landry-Guillain-Barré-Strohl syndrome, or polyradiculoneuropathy: historical review, report on 97 patients, and present concepts. Proc. Mayo Clin., 39, 427-451

Wilkinson, P. C. (1964). Serological findings in carcinomatous neuromyopathy. Lancet, 1, 1301-1303.

- and Zeromski, J. (1965). Immunofluorescent detection of antibodies against neurones in sensory carcinomatous neuropathy. Brain, 88, 529-538.

Williams, H. M., Diamond, H. D., Craver, L. F., and Parsons, H. (1959). Neurological Complications of Lymphomas and Leukemias, pp. 92-95. Thomas, Springfield, Ill.

\section{BIBLIOGRAPHY}

${ }^{1}$ Levison, P. and Møller, P. F. (1924). Myelomatose. Ugeskr. Laeg. 8b, 67-73.
${ }^{2}$ Neel, A. W. (1931). Die Bedeutung der Eiweissvermehrung ohne gleichzeitige entsprechende Zellvellvermehrung in der Spinalflüssigkeit. Dtsch. Z. nervenheilk., 117-119, 309-330.

${ }^{3}$ Davison, C., and Balser, B. H. (1937). Myeloma and its neural complications. Arch. Surg. (Chic.), 35, 913-936.

${ }^{4}$ Lindeboom, G. B., and Mulder, H. J. (1941). Multiples Myelom mit leukämischem Blutbild und degenerativen Rückenmarksänderungen. Acta med. scand., 108, 363-373.

${ }^{5}$ Massachusetts General Hospital. (1946). Case Records, No. 32231. New Eng. J. Med., 234, 763-766.

'Lawrence, J. H., and Rosenthal, R. L. (1949). Multiple myeloma associated with polycythemia. Report of four cases. Amer. J. med. Sci., 218, 149-154.

'White, S., and Tillinghast, A. J. (1950). Multiple myeloma. An analysis of twenty-one proved cases. Amer. J. Roent genol., 63, 851-864.

${ }^{8}$ Snapper, I., Turner, L. B., and Moscovitz, H. L. (1953). Multiple Myeloma, pp. 33-34. Grune and Stratton. New York.

${ }^{\circ}$ Kenny, J. J., and Moloney, W. C. (1956). Long-term survival in multiple myeloma: report of three cases Ann. intern. Med., 45, 950-957.

${ }^{10}$ Dumas, L. W., Rentschler, E. H., and Earle, K. M. (1957). Peripheral neuropathy associated with multiple myelomatosis and amyloidosis. Report of a case. Dis. nerv. Syst., 18, 419-424.

${ }^{11}$ Hassan, A. H., and Yousef, M. M. (1959). Neurological complications of multiple myelomatosis. Two case reports. J. Egypt. med. Ass., 42, 386-394.

${ }^{12}$ Campbell, A. M. G., and Halford, M. E. H. (1964). Syndrome of diarrhoea and peripheral nerve changes due to generalized vascular disease. Brit. med. J., 2, 1509-1510.

${ }^{13}$ Rypins, E. L. (1933). An unusual roentgenologic finding in multiple myeloma. Amer. J. Roent genol., 30, 56-58.

${ }^{14}$ Krainin, P., D'Angio, C. J., and Smelin, A. (1949). Multiple myeloma with new bone formation. Arch. intern. Med., 84, 976-982.

${ }^{15}$ Kohler, L. M., and Laur, A. (1950). Osteosklerose bei Plasmozytom. Bericht über einen Fall. Fortschr. Rönt genstr., 72, 714-717.

${ }^{16}$ Biondetti, P. (1952). Mieloma multiplo osteoplastico. Radiol. med. (Torino), 38, 1076-1079.

${ }^{17}$ Sharnoff, J. G., Belsky, H., and Melton, J. (1954). Plasma cell leukemia or multiple myeloma with osteosclerosis. Amer. J. Med., 17, 582-584.

${ }^{18}$ Videbaek, A. (1956). Unusual cases of osteomyelosclerosis. Acta med. scand., 153, 459-465.

${ }^{19}$ Hodler, J. (1958). Uber das Vorkommen osteoplastischer Knochenveränderungen bei der Kaplerschen Krankheit. Schweiz. med. Wschr., 88, 1065-1067.

${ }^{20}$ Lewin, H., and Stein, J. M. (1958). Solitary plasma cell myeloma with new bone formation. Amer. J. Roen genol., 79, 630-637.

${ }^{21}$ Engels, E. P., Smith, R. C., and Krantz, S. (1960). Bone sclerosis in multiple myeloma. Radiology, 74, 242-247.

${ }^{22}$ Lichtwitz, A., Sèze, S. de, Hioco, D., Bordier, P., and Mazabraud, A. (1960). La forme ostéoblastique du myélome. Sem. Hôp. Paris, 36, 1267-1270.

${ }^{23}$ Porter, E. C. (1961). Osteogenesis in multiple myeloma. Report of a case. Radiology, 76, 457-458.

${ }^{24}$ Tuboku-Metzger, A. F. (1961). Plasmacytoma with unusual radiological findings in the bones. Brit. J. Radiol., 34, 529-530.

${ }^{25}$ Yentis, I. (1961). Radiological aspects of myelomatosis. Clin. Radiol., 12, 1-7.

${ }^{26}$ Lessen, H, van, and Gellissen, K. (1961). Plasmacelluläre Retikulose und Osteosklerose. Z. Krebsforsch., 60, 200-207.

${ }^{27}$ Fairley, G. H., Jackson, D. C., and McDonald, P. (1964). Osteosclerosis in myelomatosis. Brit. J. Radiol., 37, 852-855.

${ }^{28}$ Kurai, J. (1965). Hyperostose und Sklerotisation verursachendes Myeloma multiplex. Fortschr. Rönt genstr., 101, 296-310. 